\title{
Investigation of gene expression in primary embryonic cell line (FGBC8) from olive flounder Paralichthys olivaceus
}

\author{
Ju-Won Kim*, Ja Young Cho, Won-Kyong Chun, Dong-Gyun Kim, Bo-Hye Nam, Eun-Soo Nho, \\ Young-Ok Kim, Hee Jeong Kong \\ Biotechnology Research Division, National Institute of Fisheries Science, Busan 46083, Korea
}

\begin{abstract}
In this paper, we have reported the expression of immune-related gene in a new embryonic cell line (FGBC8) which was established from olive flounder (Paralichthys olivaceus) embryos. To explore the cell biotechnological applicability, the FGBC8 cells were incubated with the several mitogens such as lipopolysaccharide (LPS), polyinosinic-polycytidylic acid (poly I:C), flagellin, and interferon (IFN)- $\gamma$. After incubation, the expression of immune-related gene was observed in FGBC8 cells through the quantitative real-time PCR. Our results indicate that FGBC8 cells will serve as a valuable research tool for investigating host-pathogen interactions as well as cell biotechnological applications.
\end{abstract}

Keywords: Olive flounder, Embryonic cell line, Immune-related gene expression

\section{Introduction}

Primary cell culture is a powerful tool commonly used to study the cellular properties and mechanisms of isolated cells in a controlled environment (Ager-Wick et al., 2018). Especially, primary culture of fish cells has been established in many fish species (Kim et al., 2018), it is also used as an ideal model for various study areas, such as virology, immunology, genetics, developmental biology, toxicology, medicine, biotechnology (Donato et al., 2008; Wang et al., 2010).

Cell lines offer the possibility of performing experiments in a controlled environment, independent of the complexity and variability of experiments in vivo (Jensen et al., 2013). For studies of host-pathogen interactions fish cell lines have become increasingly important, contributing to elucidation of constituents of innate immunity and of bacterial and viral virulence mechanism (Villena, 2003).

In order to conduct the fundamental research for the cell biotechnological applicability, we investigated the expression of immune-related gene in a new embryonic cell line (FGBC8) which was developed in our previous study (Kim et al., 2020). To achieve this aim, we performed quantitative real-time PCR

\footnotetext{
Received: Aug 3, 2021 Revised: Sep 24, 2021 Accepted: Sep 25, 2021

*Corresponding author: Ju-Won Kim

Biotechnology Research Division, National Institute of Fisheries Science (NIFS), Busan 46083, Korea

Tel: +82-51-720-2457, Fax: +82-51-720-2456, E-mail: ogamzar@korea.kr
}

This is an Open Access article distributed under the terms of the Creative Commons Attribution Non-Commercial License (http://creativecommons.org/licenses/by$\mathrm{nc} / 4.0 /$ ) which permits unrestricted non-commercial use, distribution, and reproduction in any medium, provided the original work is properly cited.

Copyright $(\odot) 2021$ The Korean Society of Fisheries and Aquatic Science 
(qRT-PCR) to observe the expression level of immune genes in FGBC8 cells following treatment with the several mitogens such as lipopolysaccharide (LPS), polyinosinic-polycytidylic acid (poly I:C), flagellin, and interferon (IFN) $-\gamma$.

\section{Materials and Methods}

\section{Primary cell culture and subculture}

A new olive flounder embryonic cell line called OFEC18-FGBC (FGBC8) was developed by our previous study (Kim et al., 2020). In order to subculture, cell culture media was arranged (L-15 medium containing 10\% FBS and 2\% AA) with $1 \%$ fish serum and $0.1 \%$ growth factor (basal fibroblast growth factor, Corning, Corning, NY, USA). Upon reaching 90\% confluence, the cells were subcultured at a ratio of 2:3 as described our previous study (Kim et al., 2020).

\section{Investigation of gene expression}

FGBC8 cells $\left(3.3 \times 10^{5}\right.$ cells/well, 40 passages $)$ were incubated overnight at $20^{\circ} \mathrm{C}$ in 6-well plates (Corning) and lipopolysaccharide (LPS; 10 and $50 \mu \mathrm{g} / \mathrm{mL})$, Poly (I:C) $(20 \mu \mathrm{g} / \mathrm{mL})$, flagellin $(5 \mu \mathrm{g} / \mathrm{mL})$ or interferon $(\mathrm{IFN})-\gamma(100 \mathrm{ng} / \mathrm{mL})$ were added then incubated for 6 hours. Total RNA was isolated using TRIzol reagent and the RNA Extraction Kit (QIAGEN, Hilden, Germany). The first-strand cDNA synthesis was conducted using a first-strand cDNA synthesis kit (Roche, Basel, Switzerland) according to the manufacturer's instructions.

qRT-PCR was performed following our previous study (Kim et al., 2020). Thermal cycling and fluorescence detection were performed using Fast SYBR Green Master Mix and SDS 7500 system (PE Applied Biosystems, Waltham, MA, USA). The immune gene expression analysis was conducted using the comparative $\mathrm{Ct}$ $\left(2^{-\Delta \Delta \mathrm{CT}}\right)$ method with 18 s ribosomal RNA gene as a control. All samples analysis was performed in three replicates. The primers sequences used in this study are listed in Table 1.

Results were subjected to one-way analysis of variance (ANOVA) followed by Fisher's protected least significant difference (PLSD) test using SPSS version 18 software. For all analyses, a $p$-value $<0.05$ was taken to indicate statistical significance. All data represent the mean $\pm \mathrm{SD}$.

\section{Result and Discussion}

A new olive flounder cell line called OFEC18-FGBC (FGBC8)

Table 1. Primers used in this study

\begin{tabular}{|c|c|c|c|}
\hline Target gene & Primer & Sequence $\left(5^{\prime}-3^{\prime}\right)$ & Length $(b p)$ \\
\hline \multirow[t]{2}{*}{ Interleukin-1 beta (IL-1 $\beta$ ) } & PolL-1b-F & CAGCACATCAGAGCAAGACAACA & 62 \\
\hline & PolL-1b-R & TGGTAGCACCGGGCATTCT & \\
\hline \multirow[t]{2}{*}{ Interleukin-6 (IL-6) } & PolL-6-F & CAGCTGCTCCAAGACATGGA & 62 \\
\hline & PolL-6-R & GATGTTGTGCGCCGTCATC & \\
\hline \multirow[t]{2}{*}{ Interleukin-1 receptor type 2-like (IL-1Rtype2) } & PolL-1R2-F & TTTAACTGCCACAGGTCTTC & 172 \\
\hline & Poll-1R2-R & TCACTTCTCATGCGCTTCT & \\
\hline \multirow[t]{2}{*}{ Interferon gamma (IFN $\gamma$ ) } & PolFN $\gamma-F$ & GAGCTGCAGTGGATGTACGA & 99 \\
\hline & PolFN $\gamma-R$ & TTTTGACCTTCCGAGCTTGT & \\
\hline \multirow[t]{2}{*}{ Tumor necrosis factor alpha (TNFa) } & PoTNFa-F & CCGACTCGATGTGTAAGGTG & 166 \\
\hline & PoTNFa-R & GTTGTCGGGTTCTGTTTTCTC & \\
\hline \multirow[t]{2}{*}{ Signal transducer and activator of transcription 1-alpha/beta-like (STAT1) } & PoSTAT1-F & CTGATCGGGAGGATGTGCTT & 91 \\
\hline & POSTAT1-R & AGTAATGCCTGGATGACGTTCA & \\
\hline \multirow[t]{2}{*}{ Interferon regulatory factor 1-like (IRF1) } & PolRF1-F & CGTTGCCTGACATTGAGGAG & 187 \\
\hline & PolRF1-R & GGCGACTGAGTGTCGCTGTA & \\
\hline \multirow[t]{2}{*}{ Interferon regulatory factor 5 (IRF5) } & PolRF5-F & CTTCCTTCCAGCTCTGATCC & 97 \\
\hline & PolRF5-R & AACCACCTGAACGATGATGA & \\
\hline \multirow[t]{2}{*}{ Interferon regulatory factor 10 (IRF10) } & PolRF10-F & CCCAACAAACTTGAGCGAGAAA & 71 \\
\hline & PolRF10-R & CCTCTGCAGCTCGCTGACA & \\
\hline \multirow[t]{2}{*}{18 s ribosomal RNA gene (18s rRNA) } & Po18s-F & ATGGCCGTTCTTAGTTGGTG & 217 \\
\hline & Po18s-R & CACACGCTGATCCAGTCAGT & \\
\hline
\end{tabular}


was developed by primary cell culture of blastula-stage embryos as described in our previous study (Kim et al., 2020). To explore the cell biotechnological applicability, the expression of immune related genes upon the mitogens such as LPS, poly I:C, flagellin, and IFN- $\gamma$ were examined using quantitative real-time PCR.

Following immune stimulation, the expression of several immune-related genes was induced in FGBC8 cells. LPS is an essential component of endotoxin, also the release by heterophil granulocytes and monocytes/macrophages of many inflammatory cytokines, which have toxic effects on cells (Qin et al., 2009). Previous studies had been reported that the LPS induced the expression of fish IL-1 $\beta$ (Hong et al., 2003; Jiang et al., 2008).
However, the PoIL-1 $\beta$ was strongly expressed by the flagellin stimulation, in this study (Fig. 1A).

Flagellin is a component of the bacterial flagellum and induces pulmonary inflammation (Liaudet et al., 2003; Ritter et al., 2005). Recognition of flagellin by TLR5 triggers the MyD88-dependent signaling pathway, and the resulting activation of NF- $\kappa \mathrm{B}$ induces the expression of proinflammatory genes, including TNF- $\alpha$ and IL-6 (Hwang et al., 2010). Interestingly, the lowest expression of PoIL- 6 was observed after the flagellin stimulation (Fig. 1B), whereas PoIL-1Rtype2 and PoTNF- $\alpha$ were highly expressed by the flagellin (Fig. 1C, D).

During an innate immune response, IFN- $\gamma$ is produced by
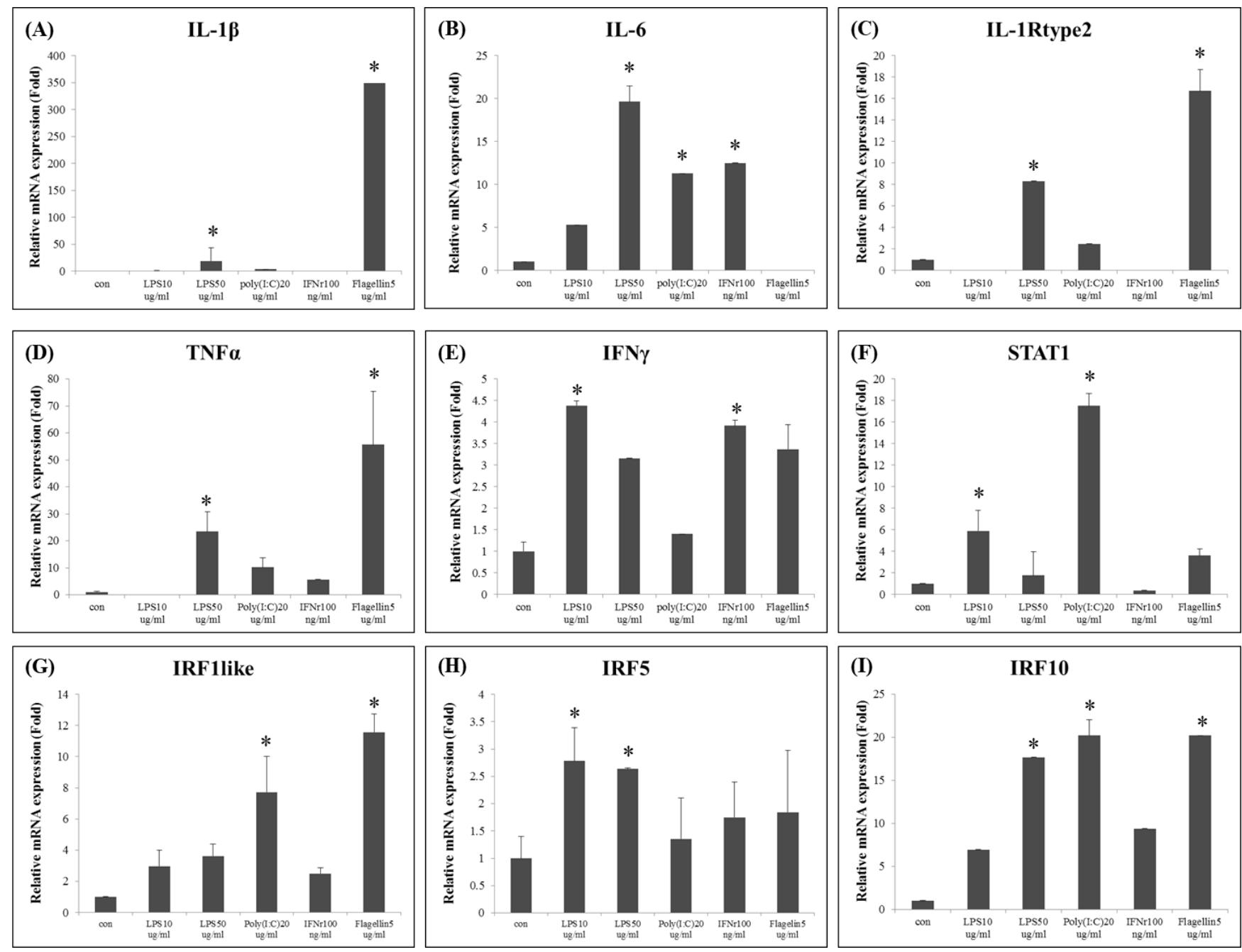

Fig. 1. The expressions of immune related genes in the FGBC8 cells that were stimulated lipopolysaccharide (LPS, 10 and 50 $\mu \mathrm{g} / \mathrm{mL}$ ), polyinosinic-polycytidylic acid (poly l:C, $20 \mu \mathrm{g} / \mathrm{mL}$ ), flagellin (5 $\mu \mathrm{g} / \mathrm{mL}$ ), and interferon (IFN)- $\boldsymbol{\gamma}(100 \mathrm{ng} / \mathrm{mL}$ ) for $6 \mathrm{hours}$. The levels of each gene expression were quantified relative to $18 \mathrm{~s}$ rRNA. Data are presented as the mean \pm SD from three independent cDNA samples with three replicates for each sample. Asterisks indicate significant differences $\left({ }^{*} p<0.05\right)$ compared to the control. 
natural killer cells following stimulation by IL-12 and/or IL-18 secreted by mononuclear phagocytes and antigen-presenting cells infected with intracellular pathogens (Jung et al., 2012). STAT1 is critical for the activity of IFNs and innate immunity (Park et al., 2008), moreover, the IRF-1 regulates IFN activity in fish (Collet \& Secombes, 2002). Additionally, IRF10 is known to be involved in the function of leukocytes as well as the type 1 IFN response and the inflammatory response following pathogen infection in teleost fish (Suzuki et al., 2011). In this study, distinct expression level of immune genes such as PoIFN- $\gamma$, PoSTAT1, PoIRF1, PoIRF5, and PoIRF10 was observed in FGBC8 cells (Fig. 1E, F, G, H, and I) after all of immunostimulants.

In conclusion, our results demonstrate that FGBC8 cells will serve as a valuable research tool for further investigation of host-pathogen interactions and it is prospected that this cell line can be useful for cell biotechnological applications.

\section{Competing interests}

No potential conflict of interest relevant to this article was reported.

\section{Funding sources}

This research was supported by a research project (R2021025) managed by the National Institute of Fisheries Science (NIFS), Korea.

\section{Acknowledgements}

Not applicable.

\section{Availability of data and materials}

Upon reasonable request, the datasets of this study can be available from the corresponding author.

\section{Ethics approval and consent to participate}

This article does not require IRB/IACUC approval because there are no human and animal participants.

\section{ORCID}

Ju-Won Kim

Ja Young Cho

Won-Kyong Chun

Dong-Gyun Kim

Bo-Hye Nam

Eun-Soo Nho

Young-Ok Kim
Hee Jeong Kong

https://orcid.org/0000-0001-6524-6544

\section{References}

Ager-Wick E, Hodne K, Fontaine R, von Krogh K, Haug TM, Weltzien FA. Preparation of a high-quality primary cell culture from fish pituitaries. J Vis Exp. 2018;138:58159.

Collet B, Secombes CJ. Type I-interferon signalling in fish. Fish Shellfish Immunol. 2002;12:389-97.

Donato MT, Lahoz A, Castell JV, Gómez-Lechón MJ. Cell lines: a tool for in vitro drug metabolism studies. Curr Drug Metab. 2008;9:1-11.

Hong S, Peddie S, Campos-Pérez JJ, Zou J, Secombes CJ. The effect of intraperitoneally administered recombinant IL- $1 \beta$ on immune parameters and resistance to Aeromonas salmonicida in the rainbow trout (Oncorhynchus mykiss). Dev Comp Immunol. 2003;27:801-12.

Hwang SD, Asahi T, Kondo H, Hirono I, Aoki T. Molecular cloning and expression study on Toll-like receptor 5 paralogs in Japanese flounder, Paralichthys olivaceus. Fish Shellfish Immunol. 2010;29:630-8.

Jensen I, Steiro K, Sommer AI, Mennen S, Johansen A, Sandaker EK, et al. Establishing a cell line from Atlantic cod as a novel tool for in vitro studies. Fish Shellfish Immunol. 2013;34:199-208.

Jiang S, Zhang D, Li J, Liu Z. Molecular characterization, recombinant expression and bioactivity analysis of the interleukin-1 $\beta$ from the yellowfin sea bream, Acanthopagrus latus (Houttuyn). Fish Shellfish Immunol. 2008;24:323-36.

Jung CY, Hikima J, Ohtani M, Jang HB, del Castillo CS, Nho SW, et al. Recombinant interferon- $\gamma$ activates immune responses against Edwardsiella tarda infection in the olive flounder, Paralichthys olivaceus. Fish Shellfish Immunol. 2012;33:197-203.

Kim JW, Cho JY, Kim J, Kim DG, Nam BH, Kim YO, et al. First report of cathepsin $\mathrm{E}$ in a teleost (Korean rose bitterling, Rhodeus uyekii): molecular characterisation and tissue distribution. Dev Comp Immunol. 2020;106:103607.

Kim JW, Oh BG, Kim J, Kim DG, Nam BH, Kim YO, et al. Development and characterization of a new cell line from olive flounder Paralichthys olivaceus. Dev Reprod. 2018;22:22534.

Liaudet L, Szabó C, Evgenov OV, Murthy KG, Pacher P, Virág L, et al. Flagellin from gram-negative bacteria is a potent mediator of acute pulmonary inflammation in sepsis. Shock. 
2003;19;131-7.

Park EM, Kang JH, Seo JS, Kim G, Chung J, Choi TJ. Molecular cloning and expression analysis of the STAT1 gene from olive flounder, Paralichthys olivaceus. BMC Immunol. 2008;9:31.

Qin L, Wang R, Li S, Li C. Differentially gene expression profile related to inflammation in endometrial cells induce by lipopolysaccharide. Reprod Contracept. 2009;20:27-34.

Ritter M, Mennerich D, Weith A, Seither P. Characterization of Toll-like receptors in primary lung epithelial cells: strong impact of the TLR3 ligand poly (I:C) on the regulation of Toll-like receptors, adaptor proteins and inflammatory response. J Inflamm. 2005;2:16.

Suzuki Y, Yasuike M, Kondo H, Aoki T, Hirono I. Molecular cloning and expression analysis of interferon regulatory factor 10 (IRF10) in Japanese flounder, Paralichthys olivaceus. Fish Shellfish Immunol. 2011;30:67-76.

Villena AJ. Applications and needs of fish and shellfish cell culture for disease control in aquaculture. Rev Fish Biol Fish. 2003;13:111-40.

Wang XL, Wang N, Sha ZX, Chen SL. Establishment, characterization of a new cell line from heart of half smooth tongue sole (Cynoglossus semilaevis). Fish Physiol Biochem. 2010;36:1181-9. 